\title{
The Sustainability of Local Media Within the Domination of National Media Industry
}

\author{
Eni Maryani ${ }^{1, *}$, Siti Karlinah ${ }^{1}$, Detta Rahmawan $^{1}$ \\ ${ }^{1}$ Faculty of Communication Science, Universitas Padjajaran Jl. Raya Bandung Sumedang KM.21, Hegarmanah, Jatinangor, \\ Kabupaten Sumedang, Jawa Barat 45363
}

\begin{abstract}
Indonesia's current condition on regional and policy still show inequality between the Java and other regions, such as in the West and East Indonesia. The gap is also apparent in the context of media, where in various regions in Indonesia, the dominance of national media is still very visible. This research uses case study to analyze the sustainability of local media in Manado and the kind of efforts that have been done to encourage the development of local media in overcoming the domination of national media industry. Through interviews, observations and literature studies, this study shows that the efforts to develop local media in Manado are still hindered by various constraints from the aspects of policy and business. There is an opportunity for the sustainability of local media in Manado but it is necessary to have supervision and guidance for management and media business. As long as local media network obeyed the rules and understand the main purpose of local media's existence, their presence can be seen as an opportunity to reduce the dominance of the national media industry. In addition, continuous support from local government and local people is important for the sustainability of local media in Manado.
\end{abstract}

Keywords: Local Media, Media Industry, Equality, Domination

\section{Introduction}

Media policy in Indonesia experienced significant changes during post-reform 1998 era. The Press Law No. 40/1999 provide opportunities for the development of healthier press in Indonesia. The abolition of SIUP (Surat Izin Usaha Penerbitan Pers/Press Publication Business Permit) and various forms of government intervention on the survival of press agency give optimism to the life of the media both in terms of business and politics. The enactment of Broadcasting Law No. 32/2002 has been widely acknowledged as more pro-public law comparing to previous Law. Referring to the broadcasting law, one of the most important policy is the establishment of four types of broadcasting institutions that accommodate the needs of the people; public broadcasters, commercial broadcasters, community broadcasters and subscriptionbased broadcasters. In relation to commercial broadcasters, the law has determined that commercial broadcasting institutions comprise of network broadcasters and local broadcasters. However, in reality, the implementation of these media-related policies is far from ideal. As will be further explained, violations of the law still occur.

This study is conducted to see the sustainability of local media, especially in the midst of a national media domination. Using the perspective of media economics, we want to explain how the local media industry thrive in the uncertainty of broadcasting law in Indonesia, and what kind of efforts have been done by the local media to maintain its business and fulfill the needs of local people for local content. Furthermore, this article also looks at various factors of technological convergence which affects the daily operational of the media, since internet penetration in Indonesia is increasing rapidly every year[1], digitalization and the utilization of new platform for content distribution is essential for media convergence strategy[2].

\section{Methodology}

Based on our literature review, it can be said that study on local media industry in Indonesia is still limited. This is caused by Indonesia's vast environment so media access becomes limited and rarely to found.To complement previous studies, used case study method[3]to analyze the local media industry in Manado. We collected data through in-depth interview, observation, and literature study. Interviews were conducted to ten people consisting of local media managers and local media audiences in Manado. Data field collection was conducted in June 2017.

\section{Discussion}

Media economics refer to all business and financial activities related to the media industry[4]. This perspective explores "the changing economic forces that direct and constrain the choices of managers, practitioners and other decision-makers across the media"[5], and also on how media companies meet the desires and needs of information and entertainment from

*Corresponding author: eni.maryani@unpad.ac.id 
audiences, advertisers and communities with limited resources[6]. The study of media economics also sees how media companies implement horizontal, vertical and diagonal development strategies. A horizontal business development strategy occurs when two or more media businesses merge in the same field. This strategy is commonly done to unite economic forces between two companies and develop their own market share. Vertical business development strategy is a strategy whereby a media company develops a business line from upstream to downstream, or in other words a media company controls everything from production line, consumption, to distribution and exhibition. This strategy aims to reduce operational costs and increased control over the media products. The third strategy is diagonal business development. Media could also develop different types of businesses, such as mergers between radio companies and television media companies. By doing diagonal development strategy, it is hoped that there will be an opportunity to bring in new sources of income. This diagonal business development strategy also triggered a transnational media development, with a decentralized management structure[7].

Currently, there are twelve media groups that control almost all media channels in Indonesia, including the local media. As a profit-driven institution, some of these large media groups have begun to buy small local media and "converted" them to be part of their network[8]. For example, Jawa Pos National Network own 20 local television stations throughout Indonesia, while Sindo TV (part of MNC Group) has 17 local television stations. Furthermore, many other local television stations are partners of the larger groups[9].

In order to keep their business, profit-driven logic in media, management must be used, that is, the media often needed to favor profit over public interest. The media need to do this, or else they will get low sales and ratings, which in turn will also affect their ad revenue[10]. Hence, many local media only serve to relay the broadcast produced by their national media's parent company. This is, of course, due to the concentration of capital which affects the expansion of media conglomeration.

In the absence of policy in favor of the viability of local media, the expansion of media conglomerates to the local level has made the local media's ideal functions limited. There are no specific rules to control media concentration. In the Indonesian Broadcasting Law No. $32 / 2002$, Article 18 , it has been specified that the crossownership of various media institutions need to be limited, however, the law do not explain in detail how to apply such limitation, and the ways in which the media ownership should be limited[11]. Hence, it can be said that broadcasting law in Indonesia failed to regulate the media as an industry. In practice, various ideal functions of the media, especially related to its role in society has not been able to perform well[12].

The development of local media in Manado is still hampered by various obstacles related to policy and business. The policy of granting broadcasting permits through selection from KPID to several local media entrepreneurs was problematic, due to the fact that once the permit is granted, the license is being traded commercially. Hence, the license is often being bought by the networked-national media. This becomes a question of state commitment in this case related to the role from KOMINFO (Ministry of Communication and Informatics), KPI or KPID (Indonesian Broadcasting Commission) in selecting and establishing ownership and broadcasting permit for local broadcasting media.

This study revealed that in Manado, a local broadcasting media that changed ownership and also switched its status from purely local into networkednational media experienced changes both in their organization and content. The media owner's policy on their network will greatly affect the management of local media. In Manado's media Landscape, apart from local media entrepreneurs, there are several national media that have been involved, namely Kompas Gramedia Group, Jawa Pos Group, and MNC group.

The diversity of media owners also produces different policies related to the portion of local content produced by each local media and its implications in opening opportunities for local human resources. One local media which change into networked-national media experienced a drastic decline in terms of local resources. Initially, when the local media was still owned by local media entrepreneurs, they were able to absorb local resources up to 48 personnel. But after becoming a networked-national media, they only required 24 personnel. This is because the local content produced by local media which initially were very dominant (almost 100\%), decreased into only two hours of broadcast per day or only about $20 \%$ of the whole local media content. The rest of the content is national content produced in Jakarta or other local content produced by other local media stations which in the same network or ownership. Furthermore, one of the respondent stated his disagreement on the local content removal policies as follow, "Yes, [local program] has to be eliminated... [even though] there are many citizens who ask [about discontinued] programs like...local [popular] talk show, "Warung Bacerita"' (personal Interview, Kompas TV worker, June 2017). This case also shows that, although the dominance of national media is strong, the people in Manado are still very interested in the content from local media.

In general, according to our interview with some Manado's local media managers, they all agree that Manado basically has a lot of potential to support the existence of local media. However, these aspects need to be well managed and developed to be sustainable. For example, mutually beneficial cooperation with the local government should be further improved. We found that various forms of cooperation with local government are crucial for the sustainability of Local Media. Furthermore, supervision and guidance related to media business management for local media managers is needed. Many of them complained about the increasing cost of media management, for example, one of the managers complain about the decreasing revenue, "the cost of [managing] the media is high...like electricity and others, while the income from the local media is... 
[decreasing]" (personal Interview, Manado FM worker, June 2017).

Many of the Local Media Managers feel that they have to learn more about the practice of media convergence. They feel the need to develop their content to be deployed on multiple platforms that can become new subsets of revenue, since the struggle to get revenues is getting tougher. "In the old days [there is] low competition...now...Maybe [the revenue is enough] only to survive...but to get big profit... no [it is difficult]" (personal Interview, Manado FM worker, June 2017). This leads to a variety of management efficiency, as well as creativity to find other sources of income.

Based on our analysis, it can be said that some local media owned by networked-national media do not have a clear vision related to the function of local media that must fulfill the needs of information from and for the local people. Some of the national media owner have a tendency to make their networked media only as economic institutions that can generate profit for them or become their tool to achieve or expand political power. This case is problematic since, the purpose of a networked broadcast; diversity of content[13] cannot run properly. Local media should be the most effective alternative tool in providing more relevant, local information to the people, since "there is [always] a well-established appetite for local news"[14]. Therefore, it is necessary to reinforce and expand the understanding of the Broadcasting Law to encourage the ideal development of the local media.

The presence of local media can be seen as strategy to reduce the dominance of the national media industry so as to provide opportunities to develop diversity of content and diversity of ownership in various regions in Indonesia. Such diversity is expected to increase the contribution of local media to the communities in which the media is operated.

\section{Conclusion}

This study can be concluded with the following points. First, the development of local media in Manado are still hampered by various constraints, both from the policy and business aspects. Secondly, Manado's local media Industry still have good potential to be further developed, yet, there is a need for supervision and guidance in the aspects of management and business development. Third, as long as local media networks comply with the rules and understand the main purpose of local media, their existence can be seen as an opportunity to reduce the dominance of the national media industry. Finally, based on the analysis, support from local government and local people is essential for the sustainability of local media in Manado. Although the media industry in Indonesia can be said to be growing rapidly, there are only a few studies which focused on local media industry. Thus, similar research is still needed to know the current condition of the local media in various regions of Indonesia.

\section{References}

1. APJII, "Infografis Penetrasi \& Perilaku Pengguna Internet Indonesia 2016", Asosiasi Penyelenggara Jasa Internet Indonesia , Jakarta (2016).

2. G. Lawson-Borders, "Media Organization and Convergence - Case Studies of Media Convergence Pioneers", Lawrence Erlbaum Associates Inc, New Jersey (2006).

3. W. J. Cresswell, "Qualitative Inquiry and Research Design: Choosing among Five Traditions", Sage Publication, London (1994).

4. A. Alexander, J. Owers, \& R. Carveth, (Eds.), "Media Economics: Theory and Practice (2nd ed.)", Lawrence Erlbaum Associates, Mahwah, NJ (1998).

5. G. Doyle, "Understanding Media Economics", SAGE Publications Ltd, London (2002).

6. R. Picard, "Media Economics: Concepts and Issues", SAGE, London (1989).

7. G .Doyle, "Understanding Media Economics", SAGE Publications Ltd, London (2002).

8. A. Grant and J. Wilkinson, "Understanding Media Convergence, The State of the Field", Oxford University Press, New York (2009).

9. Y. Nugroho, A. D. Putri, \& S. Laksmi, "Memetakan Lansekap Industri Media Kontemporer di Indonesia", Centre for Innovation Policy and Governance, Jakarta (2012).

10. E. S. Herman and N. Chomsky, "Manufacturing Consent: The Political Economy of Mass Media", Pantheon Books New York, New York (1998).

11. Y. Nugroho, A. D. Putri and S. Laksmi, "Memetakan Lansekap Industri Media Kontemporer di Indonesia", Centre for Innovation Policy and Governance, Jakarta (2012).

12. A. I. Yusuf, "Media Lokal dalam Konstelasi Komunikasi Politik di Daerah", Jurnal Ilmu Sosial dan Ilmu Politik, 14(3) (2011).

13. P. J. Shoemaker and S. D. Reese, "Mediating the Message in the 21st Century: A Media Sociology Perspective", Routledge, New York (2014).

14. M. Aldridge, "Understanding the Local Media", Open University Press, Berkshire (2007).

15. We Are Social, "Digital in 2017 Global Overview", Retrieved from www.wearesocial.com on 6 September, 2017 (2017).

16. A. I. Yusuf, "Media Lokal dalam Konstelasi Komunikasi Politik di Daerah", Jurnal Ilmu Sosial dan Ilmu Politik, 14(3) (2011) 